\section{Typing European Chestnut (Castanea sativa Mill.) Cultivars Using Oak Simple Sequence Repeat Markers}

\author{
P. Boccacci, A. Akkak, D. Torello Marinoni, G. Bounous, and R. Botta ${ }^{\mathbf{1}}$ \\ Dipartimento di Colture Arboree, Università degli Studi di Torino, Via Leonardo \\ da Vinci 44, 10095 Grugliasco, Torino, Italy
}

Additional index words. simple sequence repeat, microsatellite, Quercus robur, Quercus petraea, fingerprinting

\begin{abstract}
Microsatellite or simple sequence repeat (SSR) markers show many characteristics of the ideal molecular marker, and recent studies have shown that loci developed in one species may allow analysis in taxonomically related species. In this study, 52 primer pairs developed in two oak species-Quercus robur L. and Quercus petraea (Matt.) Lieb.-were used to amplify DNA of 5 chestnut cultivars; 28 of them yielded amplicons and 12 polymorphic loci were selected and used to fingerprint 12 european chestnut (Castanea sativa Mill.) cultivars grown in the Piedmont region of northwestern Italy. The number of alleles per locus ranged from 3 to 8 , mean expected heterozygosity was 0.592 (range: 0.288 to 0.868 ), and mean observed heterozygosity was 0.667 (range: 0.333 to 1.000 ). The results demonstrate the usefulness of some SSR markers isolated in Quercus for the fingerprinting and genetic mapping of Castanea cultivars.
\end{abstract}

Microsatellite or simple sequence repeat (SSR) markers show many characteristics of the ideal molecular marker: abundance in the genome, reproducibility, a high level of polymorphism, and codominant inheritance. Once an SSR-containing region has been isolated from the genome, primers can be designed from the DNA sequence of the regions that flank the repeat and used to amplify the locus using the polymerase chain reaction (PCR) and analyzed with semi-automated techniques. The DNA sequences in flanking regions are conserved within the species and often also in taxonomically related species or genera (Di Gaspero et al., 2000; Rossetto et al., 2002; Yamamoto et al., 2001). A molecular marker is considered conserved if it can be amplified in two species with the same primer pair. Conserved microsatellite loci have been reported in Citrus (Kijas et al., 1995), Quercus (Hornero et al., 2001; Steinkellner et al., 1997a), Prunus (Cipriani et al., 1999; Downey and Iezzoni, 2000), Pyrus (Akkak et al., 1998, Yamamoto et al., 2001), Picea (Hodgetts et al., 2001; Rajora et al., 2001), Fagus (Tanaka et al., 1999), Actinidia (Huang et al., 1998), and Vitis (Rossetto et al., 2002; Sefc et al., 1999). This finding may permit the analysis of different species using the same SSR loci, thus reducing the costs.

The european chestnut (Castanea sativa Mill.) is a tree of interest for both agriculture and forestry and represents, where the soil and climatic conditions are favorable, one of the

Received forpublication 5 Aug. 2003. Accepted for publication 8 Mar. 2004. The authors thank H. Steinkellner (Zentrum fuer Angewandte Genetik, Universitaet fuer Bodenkultur,Vienna,Austria)forproviding unpublished primer sequences of SSR loci, and S.A. Mehlenbacher (Oregon State University, Corvallis, Ore.) for reviewing themanuscript. This research wasfunded by the Regione PiemonteAdministration and by EU contractEVK2-CT -1999-00006, CASCADE Project.

1Corresponding author; e-mail roberto.botta@unito.it. most common species in forests around the Mediterranean basin. Chestnut cultivation in Europe was widespread in rural as well as in mountain areas until the middle of the 20th century, at which time chestnut cultivation entered a period of decline due to socio-economic changes and mountain depopulation and to the spread of diseases such as blight caused by Cryphonectria parasitica (Murr.) Barr and ink disease caused by Phytophthora cambivora (Petri) Buis. and Phytophthora cinnamomi Rand.. In the last decade of the 20th century there was a renewal of interest in the growing of chestnut in Europe, thanks to the decreased virulence of Cryphonectria parasitica and to increased demand for chestnut nuts and wood.

In this situation there is a need for the rescue, description and identification of the once widely cultivated germplasm and for the restoration of old plantations. In fact, in spite of the abandonment of old plantations and of the widespread distribution of blight, most trees survived indicating that adult trees of Castanea sativa were able to tolerate attack by the fungus even before the introduction of hypovirulent strains. During the past decade, the understory has been removed from many plantations, trees 70 to 150 years old have been pruned and good productivity has been restored.

Germplasm collection and characterization has been carried out in Spain, France, Italy and Greece and genetic studies on both cultivated and wild populations have been conducted by several authors (Fineschi et al., 1993; Goulao et al., 2001; Paffetti et al., 1999; Pereira et al., 1999; Pereira-Lorenzo and Fernandez-Lopez, 1993; Pereira-Lorenzo et al., 1996; Santana et al., 1999; Villani et al., 1991, 1993) using isozyme, randomly amplified polymorphic DNA (RAPD) and inter-simple sequence repeat (ISSR) markers, with the aim of assessing genetic variability, constructing phylogenetic trees and fingerprinting cultivars. In addition, linkage maps for Castanea have been constructed (Barreneche et al., 2003; Casasoli et al., 2001; Kubisiak et al., 1997). SSR markers have only recently been isolated from $C$. sativa (Buck et al., 2003; Marinoni et al., 2003).

Preliminary research (Botta et al., 1999; Steinkellner et al., 1997a) showed that primers developed for some SSR loci in two species of oak, Quercus robur L. (Kampfer et al., 1998) and Quercus petraea (Matt.) Lieb. (Steinkellner et al., 1997b), would also amplify chestnut DNA. This paper identifies the oak SSR loci most useful for fingerprinting chestnut cultivars.

\section{Materials and Methods}

Plant material and DNA extraction. 'Marigoule' (Castanea crenata Sieb. et Zucc. X Castanea sativa Mill.), 12 C. sativa individuals representing the cultivars grown in different valleys of the Piedmont region of northwestern Italy (Table 1), and two individuals of $Q$. petraea were used. For evaluating polymorphism in the selected SSR loci, a group of 12 cultivars was chosen. The group included 'Marrone di Chiusa Pesio' which is of high interest for the quality of its nuts, 'Garrone Rosso' and 'Garrone Nero', which are considered related to 'Marrone', and other cultivars that are genetically more distant.

DNA was extracted from $0.5 \mathrm{~g}$ of leaves using the procedure described by Thomas et al. (1993) in a Tris-EDTA-NaCl buffer containing $0.25 \mathrm{M} \mathrm{NaCl}, 0.2 \mathrm{M}$ Tris- $\mathrm{HCl} \mathrm{pH} 7.6$, $2.5 \%$ PVP (molecular weight 40,000), $0.05 \mathrm{M}$ $\mathrm{Na}_{2}$ EDTA pH 8.0, 3\% sarcosyl, 20\% ethanol and $1 \% \beta$-mercaptoethanol. After purification the DNA was suspended in $70 \mu \mathrm{L}$ Tris-EDTA buffer.

Microsatellite PCR amplification and analysis. Primer pairs designed for 41 loci from Quercus robur (Kampfer et al., 1998) and 11 from $Q$. petraea (Steinkellner et al., 1997b) were used to amplify DNA of five chestnut cultivars ('Marrone di Luserna', 'Gioviasca', 'Pelosa piccola', 'Pelosa grossa', and 'Marigoule'). The primer sequences for 10 loci from $Q$. robur were unpublished and were kindly provided by Steinkellner (Zentrum fuer Angewandte Genetik, Universitaet fuer Bodenkultur, Vienna). DNA of the two $Q$. petraea individuals was included as positive controls.

PCR was performed in a volume of 20 $\mu \mathrm{L}$ containing 50 ng DNA, $0.5 \mathrm{U}$ Taq-DNA polymerase (AmpliTaq Gold polymerase, Applied-Biosystems), $2 \mu \mathrm{L}$ 10× PCR buffer (100 mм Tris-HCl, pH 8.3, 500 mм KCl), 1.8 $\mathrm{mm} \mathrm{MgCl} 2,200 \mu \mathrm{M}$ dNTPs and $0.5 \mu \mathrm{m}$ of each primer. A DNA Thermal Cycler 480 (Perkin Elmer Cetus) was used and the PCR conditions were: first a denaturation step at $95{ }^{\circ} \mathrm{C}$ for 10 min followed by 26 cycles of denaturation $\left(50 \mathrm{~s}\right.$ at $\left.95^{\circ} \mathrm{C}\right)$, annealing ( $45 \mathrm{~s}$ at the optimal temperature for Quercus for each primer pair and ranging from 45 to $60{ }^{\circ} \mathrm{C}$, Table 3 ) and extension $\left(90 \mathrm{~s}\right.$ at $\left.72^{\circ} \mathrm{C}\right)$. The final elongation step was at $72{ }^{\circ} \mathrm{C}$ for $7 \mathrm{~min}$.

The PCR products were separated by elec- 
Table 1. Allele sizes (in base pairs) at 12 SSR loci in 12 chestnut cultivars grown in the Piedmont region of northwestern Italy. The (-) sign was used when only one allele was detected, the missing allele could be of the same size (homozygous individuals) or could be a null allele (heterozygous individuals)

\begin{tabular}{|c|c|c|c|c|c|c|c|c|c|c|c|c|c|c|c|c|c|c|c|c|c|c|c|c|c|}
\hline \multirow{3}{*}{$\begin{array}{l}\text { DNA } \\
\text { code } \\
\text { C26 }\end{array}$} & \multirow{3}{*}{$\begin{array}{l}\text { Cultivar } \\
\text { Garrone rosso }\end{array}$} & \multicolumn{24}{|c|}{ Allele } \\
\hline & & \multicolumn{2}{|c|}{ QrZAG7 } & \multicolumn{2}{|c|}{ QrZAG20 } & \multicolumn{2}{|c|}{ QrZAG75 } & \multicolumn{2}{|c|}{ QrZAG96 } & \multicolumn{2}{|c|}{ QrZAG101 } & \multicolumn{2}{|c|}{ QrZAG121 } & \multicolumn{2}{|c|}{ QpZAG15 } & \multicolumn{2}{|c|}{ QpZAG16 } & \multicolumn{2}{|c|}{ QpZAG36 } & \multicolumn{2}{|c|}{ QpZAG46 } & \multicolumn{2}{|c|}{ QpZAG110 } & \multicolumn{2}{|c|}{ QpZAG119 } \\
\hline & & 122 & 124 & 173 & 177 & 164 & - & 155 & 160 & 127 & 129 & 217 & - & 120 & 128 & 158 & 160 & 217 & 223 & 192 & 194 & 210 & 219 & 64 & 92 \\
\hline C57 & Gabiana & 120 & 124 & 177 & - & 164 & 166 & 155 & 160 & 129 & - & 215 & 217 & 120 & 128 & 160 & - & 221 & 223 & 194 & - & 213 & 219 & 78 & 92 \\
\hline C37 & Garrone nero & 122 & 124 & 173 & 177 & 112 & 164 & 155 & 160 & 129 & 155 & 217 & - & 128 & - & 160 & - & 217 & 221 & 192 & 194 & 210 & 219 & 64 & 78 \\
\hline C67 & Gentile & 122 & 124 & 161 & 179 & 132 & - & 155 & 157 & 129 & 155 & 217 & - & 120 & 128 & 160 & - & 217 & 221 & 192 & 194 & 210 & 213 & 64 & 78 \\
\hline $\mathrm{C} 06$ & Gioviasca & 120 & 124 & 173 & 179 & 136 & 155 & 155 & - & 129 & - & 217 & 223 & 128 & - & 160 & 162 & 217 & 221 & 192 & 194 & 213 & 219 & 64 & 86 \\
\hline $\mathrm{C} 19$ & Lusench & 120 & - & 179 & - & 136 & 166 & 155 & 162 & 129 & - & 217 & - & 118 & 128 & 158 & 160 & 221 & 223 & 194 & - & 213 & 219 & 64 & 86 \\
\hline $\mathrm{C} 10$ & Madonna & 120 & 124 & 173 & - & 140 & 155 & 155 & 166 & 129 & 155 & 217 & - & 120 & 128 & 160 & - & 217 & 221 & 192 & 196 & 210 & 230 & 86 & 92 \\
\hline $\mathrm{C} 22$ & Marrone di Chiusa Pesio & 120 & 122 & 173 & 179 & 112 & - & 155 & 157 & 127 & 155 & 217 & - & 128 & - & 160 & - & 217 & 221 & 192 & 194 & 210 & - & 64 & 86 \\
\hline $\mathrm{C} 09$ & Pelosa grossa & 120 & 124 & 173 & - & 140 & - & 155 & 160 & 129 & - & 217 & 223 & 120 & 128 & 158 & 162 & 217 & 221 & 192 & 194 & 213 & 219 & 64 & 86 \\
\hline $\mathrm{C} 17$ & Pelouset & 120 & - & 167 & - & 136 & 145 & 160 & - & 129 & - & 217 & - & 128 & - & 160 & - & 219 & 221 & 194 & - & 219 & 230 & 86 & - \\
\hline $\mathrm{C} 83$ & Ruiana & 120 & 124 & 159 & 179 & 145 & 166 & 155 & - & 129 & - & 217 & - & 128 & - & 158 & 160 & 217 & 221 & 192 & 194 & 213 & - & 64 & 76 \\
\hline $\mathrm{C} 16$ & Tempuriva & 120 & - & 173 & - & 136 & 155 & 155 & - & 127 & 155 & 217 & 223 & 128 & 132 & 158 & 160 & 211 & 221 & 194 & 198 & 213 & 219 & 64 & 86 \\
\hline
\end{tabular}

trophoresis on a $8 \times 10$-cm polyacrylamide gel and stained with ethidium bromide to verify amplification. Loci which showed good amplification were then analyzed on sequencing gels using chemiluminescent detection.

One microliter of each sample was run, after denaturation in $1 \mu \mathrm{L}$ of loading buffer $(95 \%$ formamide, $20 \mathrm{~mm}$ EDTA, $0.05 \%$ bromophenol blue, $0.05 \%$ xylene cyanole) at $95{ }^{\circ} \mathrm{C}$ for $3 \mathrm{~min}$, on a $50 \times 21-\mathrm{cm}$ sequencing gel $(6 \%$ polyacrylamide $24: 1,8 \mathrm{M}$ urea, $1 \times \mathrm{TBE}$ buffer). After electrophoresis, DNA was blotted on a Zeta Probe (Bio-Rad, USA) positively charged nylon membrane and hybridized $1 \mathrm{~h}$ at $45^{\circ} \mathrm{C}$ in 15 to $20 \mathrm{~mL}$ of hybridization buffer (1 M EDTA, $7 \%$ SDS, $0.25 \mathrm{M}$ disodium phosphate $\mathrm{pH}$ 7.2) containing 60-120 pmol of a biotin labeled $(\mathrm{GA})_{13}$ and $(\mathrm{GT})_{13}$ probes. Chemiluminescent detection was performed using a Phototope-Star Detection Kit by New England BioLabs (USA) following the manufacturer's instructions.

Twelve cultivars of $C$. sativa were chosen for analysis at twelve selected loci using a semi-automatic system in order to evaluate SSR marker polymorphism. Two cultivars of C. sativa-'Marrone di Luserna' and 'Pelosa piccola'-were not analyzed because they were found to be synonyms of 'Marrone di Chiusa Pesio' and 'Pelosa grossa', respectively (Marinoni, 2000). The forward primer of each locus was labeled with one of the following fluorochromes: NED (yellow), HEX (green), or 6-FAM (blue).

One microliter of a mix containing amplification products of three differently labeled loci was added to $3 \mu \mathrm{L}$ of a mix containing 10:2:1 parts of formamide, GeneScan-350 ROX size standard and loading buffer (25 mM EDTA, 50 $\mathrm{mg} \cdot \mathrm{mL}^{-1}$ blue dextran) respectively. Samples were denatured at $95^{\circ} \mathrm{C}$ for $5 \mathrm{~min}$ and analyzed on a sequencing gel (4.25\% acrylamide, $1 \times$ TBE buffer, 6 M Urea) using an ABI-PRISM 377 sequencing machine. Data were analyzed with GENESCAN software and alleles were designated by their size in base pairs.

Statistical analysis. The software IDENTITY 1.0 (Wagner and Sefc, 1999) was used to calculate the number of alleles per locus and their frequency, expected and observed heterozygosity, frequency of null alleles, paternity exclusion probability and probability of finding two identical genotypes. Expected heterozygosity $(\mathrm{He})$ was calculated as $\mathrm{He}=$ $1-\sum \mathrm{p}_{\mathrm{i}^{2}}$ where $\mathrm{p}_{\mathrm{i}}$ denotes the frequency of allele $\mathrm{i}$ in the cultivars (Nei, 1973). Observed heterozygosity (Ho) was obtained from direct calculation. The null allele frequency was calculated as $\mathrm{r}=(\mathrm{He}-\mathrm{Ho}) /(1+\mathrm{He})$ where $\mathrm{He}$ $=$ expected heterozygosity and $\mathrm{Ho}=$ observed heterozygosity (Brookfield, 1996). The probability of finding two identical genotypes was calculated as $\mathrm{PI}=\sum \mathrm{p}_{1}{ }^{4}+\sum\left(2 \mathrm{p}_{\mathrm{i}} \mathrm{p}_{\mathrm{j}}\right)^{2}$, where $\mathrm{p}_{\mathrm{i}}$ and $\mathrm{p}_{j}$ are the frequencies of alleles $\mathrm{i}$ and $\mathrm{j}$, respectively (Paetkau et al., 1995).

\section{Results and Discussion}

SSR locus analysis. In this study we wanted to evaluate SSR markers developed for oak species and to select a set of loci that could be routinely used in chestnut. Our first objective was to verify in chestnut the successful amplification by each oak primer pair. Of the 52 primer pairs, $28(54 \%)$ yielded amplicons in five chestnut cultivars (Table 2), showing the existence of homologous regions in the genomes of Quercus and Castanea; successful amplification was obtained for $91 \%$ of loci from $Q$. petraea and $40.5 \%$ of loci from Q. robur. The remaining $24(46 \%)$ were not pursued further since they were able to amplify oak DNA but not chestnut, even with lower stringency conditions during PCR.

Steinkellner et al. (1997a) found that SSR markers from $Q$. petraea were present in $Q$. robur $(100 \%)$ and $Q$. pubescens Willd. (100\%), while only some of them could successfully be amplified in $Q$. cerris L. (64\%), Q. rubra L. (47\%), Q. palustris Muenchh. (47\%), and Fagus sylvatica L. (24\%). Similar results are reported by Hornero et al. (2001) for $Q$. suber L. $(54.5 \%)$. The presence of common markers across the species can be of great interest for genetic mapping (Casasoli et al., 2001; Barreneche et al., 1998) and, in particular, for comparative mapping, as demonstrated by the the results of Barreneche et al. (2003).

Yet, the successful amplification of DNA does not always mean that SSR loci are present in the amplicons. Out of 28 primer pairs that yielded amplification in chestnut, 13 were not used for further analysis. Loci ssrQrZAG4, ssrQrZAG46, ssrQrZAG87, ssrQrZAG88MS, ssrQrZAG88-TT, ssrQrZAG90, and ssrQpZAG58 yielded a number of bands higher than the two expected. In this case either the amplification is not specific enough and more regions of the genome were amplified or the
SSR locus is present in multiple copies. These loci were discarded for use in fingerprinting, as interpretation of the results would have been difficult. In some cases, specific bands are not amplified when PCR conditions were made more stringent (e.g. higher annealing temperature) but this was not the case for the mentioned loci. Loci ssrQrZAG59, ssrQrZAG73, and ssrQpZAG1/2 produced fragments of larger size (350-600 bp) in Castanea than in Quercus. These fragments may come from other regions of the genome and, even if they contain the SSR sequence, are not of practical use for fingerprinting due to the large size of the amplicons. Further three loci, ssrQrZAG31, ssrQrZAG86, and ssrQpZAG3/64, were discarded because showed weak amplification and could not be improved resulting in unclear profiles. Weak amplification may be due to mismatches in the primer annealing site.

The other 15 loci gave good amplification, the results were clear and the allele sizes were approximately the same as in oak. They were analyzed using a manual sequencing apparatus and chemiluminescent detection. Loci ssrQrZAG5, ssrQrZAG65, and ssrQrZAG112 were the least polymorphic ( $\leq 2$ alleles) and although they could be useful for mapping or other purposes, were not further considered for fingerprinting.

Twelve loci showed at least two alleles and were selected for the analysis of 12 cultivars of $C$. sativa using the automated sequencer ABI-PRISM 377 and GENESCAN software. Results (Table 1) were highly reproducible and conditions of analysis were optimized for each locus to minimize stuttering.

SSR locipolymorphism. For evaluating polymorphism in the selected set of 12 loci, a group of 12 different cultivars were chosen from the cultivated germplasm. Number of alleles, number of genotypes and expected heterozigosity are indicators used for evaluating polymorphism and discriminant power of a locus.

The number of alleles per locus ranged from 3 to 8 (Table 3). Loci ssrQrZAG75 (8 alleles) and ssrQrZAG20 (6 alleles) had the largest number of alleles.

The combination of profiles across all loci resulted in 12 different genotypes, one for each cultivar (Table 1). The highest discriminative power was shown by loci ssrQrZAG75 (11 genotypes), ssrQrZAG20 (8 genotypes) and ssrQpZAG110 (7 genotypes). 
The probability of identity (PI) for each locus ranged from 0.062 for ssrQrZAG75 to 0.579 for ssrQrZAG121 (mean: 0.339), whereas the total probability of identity was $4.58 \times 10^{-7}$.

The allele frequencies ranged from 0.042 to 0.833 (Table 4). The expected heterozygosity averaged 0.592 and ranged from 0.288 (for ssrQrZAG121) to 0.868 (for ssrQrZAG75), but the observed heterozygosity averaged 0.667 and ranged from 0.333 (for ssrQrZAG121) to 1.000 (for ssrQpZAG36).

Among loci from $Q$. petraea, observed heterozygosity in chestnut was 1.00 at ssrQpZAG36 and 0.92 at ssrQpZAG119, higher than in oak (Steinkellner et al., 1997b), while lower values were found for ssrQpZAG15, ssrQpZAG16, ssrQpZAG46, and ssrQpZAG110 (0.58, 0.50, 0.75 and 0.83 , respectively). Among loci from Q. robur, ssrQrZAG7, ssrQrZAG96, and ssrQrZAG75 showed the highest level of observed heterozygosity $(0.75$, 0.67 and 0.67 , respectively).

The possible presence of null-alleles showed positive values $(0.131$ and 0.108$)$ for ssrQrZAG20 and ssrQrZAG75, respectively.

Table 2. Results from amplification of Quercus robur and Q. petraea SSR loci in four cultivars of Castanea sativa Mill. and in hybrid 'Marigoule' (C. crenata x C. sativa).

\begin{tabular}{|c|c|c|}
\hline$\overline{\text { Locus }^{2}}$ & Amplification $^{y}$ & Results $^{x}$ \\
\hline ssrQrZAG2 & - & \\
\hline ssrQrZAG4 & + & $>2$ Bands \\
\hline ssrQrZAG5 & + & Good but monomorphic \\
\hline ssrQrZAG7 & + & Good \\
\hline ssrQrZAG11 & - & \\
\hline ssrQrZAG13 & - & \\
\hline ssrQrZAG15 & - & \\
\hline ssrQrZAG18 & - & \\
\hline ssrQrZAG19 & - & \\
\hline ssrQrZAG20 & + & Good \\
\hline ssrQrZAG25 & - & \\
\hline ssrQrZAG30 & - & \\
\hline ssrQrZAG31 & + & Weak \\
\hline ssrQrZAG39 & - & \\
\hline ssrQrZAG44 & - & \\
\hline ssrQrZAG46 & + & $>2$ Bands \\
\hline ssrQrZAG51 & - & \\
\hline ssrQrZAG52 & - & \\
\hline ssrQrZAG56 & - & \\
\hline ssrQrZAG58 & - & \\
\hline ssrQrZAG59 & + & Larger amplicons \\
\hline ssrQrZAG65 & + & Good but monomorphic \\
\hline ssrQrZAG73 & + & Larger amplicons \\
\hline ssrQrZAG75 & + & Good \\
\hline ssrQrZAG77 & - & \\
\hline ssrQrZAG82 & -_- & \\
\hline ssrQrZAG86 & + & Weak \\
\hline ssrQrZAG87 & + & $>2$ Bands \\
\hline ssrQrZAG88-MS & + & $>2$ Bands \\
\hline ssrQrZAG88-TT & + & $>2$ Bands \\
\hline ssrQrZAG90 & + & $>2$ Bands \\
\hline ssrQrZAG95 & - & \\
\hline ssrQrZAG96 & + & Good \\
\hline ssrQrZAG101 & + & Good \\
\hline ssrQrZAG102 & - & \\
\hline ssrQrZAG103 & - & \\
\hline ssrQrZAG108 & - & \\
\hline ssrQrZAG111 & - & \\
\hline ssrQrZAG112 & + & Good but monomorphic \\
\hline ssrQrZAG113 & - & \\
\hline ssrQrZAG121 & + & Good \\
\hline ssrQpZAG1/2 & + & Larger amplicons \\
\hline ssrQpZAG1/5 & - & \\
\hline ssrQpZAG3/64 & + & Weak \\
\hline ssrQpZAG15 & + & Good \\
\hline ssrQpZAG16 & + & Good \\
\hline ssrQpZAG36 & + & Good \\
\hline ssrQpZAG46 & + & Good \\
\hline ssrQpZAG58 & + & $>2$ Bands \\
\hline ssrQpZAG104 & - & \\
\hline ssrQpZAG110 & + & Good \\
\hline ssrQpZAG119 & + & Good \\
\hline
\end{tabular}

${ }^{2}$ Primer sequences, all from $Q$. robur, not previously published are ssrQrZAG13, ssrQrZAG19, ssrQrZAG46, ssrQrZAG51, ssrQrZAG52, ssrQrZAG82, ssrQrZAG86, ssrQrZAG88 MS, ssrQrZAG88 TT, and ssrQrZAG113.

y (+)Successful amplification of chestnut DNA, (-) no amplification of chestnut DNA

${ }^{\mathrm{x}} \mathrm{Good}=$ presence of 1 to 2 bands of expected size; weak = weak amplification, bands of expected size; larger amplicons $=$ size of amplicons ( 350 to $600 \mathrm{bp}$ ) larger in chestnut than in oak; $>2$ bands = presence of 3 or more bands.
The estimated frequency of null alleles was a positive value for only 2 of the 12 loci: ssrQrZAG20 (0.131) and ssrQrZAG75 (0.108). The number of studied samples was too small to draw conclusions on the occurrence of null alleles, whose presence can be truly ascertained only by studying their segregation or their frequency in a large population (Callen et al., 1993).

On the other hand, the main purpose of this paper was to evaluate the loci for their polymorphism, ease of analysis and discriminative ability. Of the 12 tested, loci ssrQrZAG20, ssrQrZAG75, ssrQrZAG96, ssrQpZAG36, ssrQpZAG110, and ssrQpZAG119 can be considered the most interesting for fingerprinting on the basis of polymorphism. Loci ssrQrZAG75 and ssrQrZAG20, in particular, produced the highest number of genotypes.

The loci could be studied in multiplex analyses (Botta et al., 2001) in combinations of 5 to 6 together or in association with the loci isolated in chestnut (Marinoni et al., 2003). For the particularly low molecular weight (64 to $92 \mathrm{bp}$ ) of its alleles, locus ssrQpZAG119 could be conveniently used without overlapping the other loci.

Loci showing less polymorphism, ssrQrZAG101, ssrQpZAG15, and ssrQpZAG110 ( $\leq 4$ alleles), should not yet be discarded, as we might expect to find new alleles if a larger number of genotypes is analyzed.

For DNA typing purposes, SSR are likely to be the most appropriate markers since they show a high level of polymorphism, are codominant and permit an easier and reliable transfer of information across laboratories (This et al., accepted). SSR show evident advantages over isoenzymes (Pereira et al., 1999; Pereira-Lorenzo and Fernandez-Lopez, 1993; Pereira-Lorenzo et al., 1996), that are much less polymorphic, and more affected by physiological and environmental conditions and by the kind of plant tissue used for extraction.

The results obtained by Goulao and Oliveira (2001) indicate that SSR markers provide a powerful tool for the fingerprinting exhibiting advantages over RAPD and AFLP. The RAPD markers, used in chestnut by Fineschi et al. (1993), Goulao et al. (2001), Paffetti et al. (1999), and Santana et al. (1999), are very sensitive to the PCR conditions and therefore are less reproducible in different laboratories. AFLP, that were used by Yamamoto et al. (1998) for the genetic characterization of Asian species of Castanea, are extremely polymorphic but are based on a complex technique that requires high DNA quality.

\section{Conclusions}

The present paper confirms that SSR loci are conserved across taxonomically related species in the Fagaceae, but that only a relatively small number (about 20\%) of the loci isolated in oak can be conveniently used for the fingerprinting of chestnut. Among them, six loci(ssrQrZAG20, ssrQrZAG75, ssrQrZAG96, ssrQpZAG36, ssrQpZAG110, and ssrQpZAG119) are recommended for routine use while at least three 
Table 3. Number of alleles with size range and number of genotypes found for 12 oak simple sequence repeat loci in 12 chestnut cultivars at the specified annealing temperature.

\begin{tabular}{lccccc}
\hline Locus & Fluorochrome & $\begin{array}{c}\text { Annealing } \\
\text { temp }\left({ }^{\circ} \mathrm{C}\right)\end{array}$ & $\begin{array}{c}\mathrm{N}^{\circ} \\
\text { alleles }\end{array}$ & $\begin{array}{c}\text { Size } \\
\text { range }\end{array}$ & $\begin{array}{c}\mathrm{N}^{\circ} \\
\text { genotypes }\end{array}$ \\
\hline ssrQrZAG7 & HEX & 52 & 3 & $120-124$ & 4 \\
ssrQrZAG20 & NED & 52 & 6 & $159-179$ & 8 \\
ssrQrZAG75 & HEX & 54 & 8 & $112-166$ & 11 \\
ssrQrZAG96 & NED & 46 & 5 & $155-166$ & 6 \\
ssrQrZAG101 & HEX & 48 & 3 & $127-155$ & 4 \\
ssrQrZAG121 & 6-FAM & 50 & 3 & $215-223$ & 3 \\
ssrQpZAG15 & 6-FAM & 54 & 4 & $118-132$ & 4 \\
ssrQpZAG16 & 6-FAM & 60 & 3 & $158-162$ & 4 \\
ssrQpZAG36 & 6-FAM & 50 & 5 & $211-223$ & 5 \\
ssrQpZAG46 & HEX & 46 & 4 & $192-198$ & 4 \\
ssrQpZAG110 & NED & 50 & 4 & $210-230$ & 7 \\
ssrQpZAG119 & NED & 46 & 5 & $64-92$ & 7 \\
\hline
\end{tabular}

Table 4. Characteristics of 12 SSR loci studied in 12 chestnut cultivars.

\begin{tabular}{|c|c|c|c|c|c|}
\hline Locus & $\begin{array}{l}\text { Allele } \\
\text { size } \\
\text { (bp) }\end{array}$ & $\begin{array}{c}\text { Allele } \\
\text { frequency }\end{array}$ & $\begin{array}{c}\text { Heterozygosity } \\
\text { expected (He) } \\
\text { and observed (Ho) }\end{array}$ & $\begin{array}{l}\text { Frequency } \\
\text { of null } \\
\text { alleles }\end{array}$ & $\begin{array}{c}\text { Probability } \\
\text { of } \\
\text { identity (PI) }\end{array}$ \\
\hline \multirow{3}{*}{ ssrQrZAG7 } & 120 & 0.500 & He: 0.611 & -0.086 & 0.378 \\
\hline & 122 & 0.167 & Ho: 0.750 & & \\
\hline & 124 & 0.333 & & & \\
\hline \multirow[t]{6}{*}{ ssrQrZAG20 } & 159 & 0.042 & He: 0.726 & 0.131 & 0.196 \\
\hline & 161 & 0.042 & Ho: 0.500 & & \\
\hline & 167 & 0.083 & & & \\
\hline & 173 & 0.417 & & & \\
\hline & 177 & 0.167 & & & \\
\hline & 179 & 0.250 & & & \\
\hline \multirow[t]{8}{*}{ ssrQrZAG75 } & 112 & 0.125 & He: 0.868 & 0.108 & 0.062 \\
\hline & 132 & 0.083 & Ho: 0.667 & & \\
\hline & 136 & 0.167 & & & \\
\hline & 140 & 0.125 & & & \\
\hline & 145 & 0.083 & & & \\
\hline & 155 & 0.125 & & & \\
\hline & 164 & 0.167 & & & \\
\hline & 166 & 0.125 & & & \\
\hline \multirow[t]{5}{*}{ ssrQrZAG96 } & 155 & 0.583 & He: 0.587 & -0.050 & 0.324 \\
\hline & 157 & 0.083 & Ho: 0.667 & & \\
\hline & 160 & 0.250 & & & \\
\hline & 162 & 0.042 & & & \\
\hline & 166 & 0.042 & & & \\
\hline \multirow{3}{*}{ ssrQrZAG101 } & 127 & 0.125 & He: 0.496 & -0.002 & 0.415 \\
\hline & 129 & 0.667 & Ho: 0.500 & & \\
\hline & 155 & 0.208 & & & \\
\hline \multirow{3}{*}{ ssrQrZAG121 } & 215 & 0.042 & He: 0.288 & -0.035 & 0.579 \\
\hline & 217 & 0.833 & Ho: 0.333 & & \\
\hline & 223 & 0.125 & & & \\
\hline \multirow[t]{4}{*}{ ssrQpZAG15 } & 118 & 0.042 & He: 0.451 & -0.091 & 0.443 \\
\hline & 120 & 0.208 & Ho: 0.583 & & \\
\hline & 128 & 0.708 & & & \\
\hline & 132 & 0.042 & & & \\
\hline \multirow[t]{3}{*}{ ssrQpZAG16 } & 158 & 0.208 & He: 0.448 & -0.036 & 0.458 \\
\hline & 160 & 0.708 & Ho: 0.500 & & \\
\hline & 162 & 0.083 & & & \\
\hline \multirow[t]{5}{*}{ ssrQpZAG36 } & 211 & 0.042 & He: 0.660 & -0.205 & 0.293 \\
\hline & 217 & 0.333 & Ho: 1.000 & & \\
\hline & 219 & 0.042 & & & \\
\hline & 221 & 0.458 & & & \\
\hline & 223 & 0.125 & & & \\
\hline \multirow[t]{4}{*}{ ssrQpZAG46 } & 192 & 0.333 & He: 0.545 & -0.132 & 0.443 \\
\hline & 194 & 0.583 & Hо: 0.750 & & \\
\hline & 196 & 0.042 & & & \\
\hline & 198 & 0.042 & & & \\
\hline \multirow[t]{4}{*}{ ssrQpZAG110 } & 210 & 0.250 & He: 0.708 & -0.073 & 0.254 \\
\hline & 213 & 0.333 & Ho: 0.833 & & \\
\hline & 219 & 0.333 & & & \\
\hline & 230 & 0.083 & & & \\
\hline \multirow{5}{*}{ ssrQpZAG119 } & 64 & 0.375 & He: 0.715 & -0.117 & 0.226 \\
\hline & 76 & 0.042 & Ho: 0.917 & & \\
\hline & 78 & 0.125 & & & \\
\hline & 86 & 0.333 & & & \\
\hline & 92 & 0.125 & & & \\
\hline
\end{tabular}

more loci (ssrQrZAG101, ssrQpZAG15, and ssrQpZAG110) also show promise. The remaining three loci plus the three discarded after the first selection (ssrQrZAG5, ssrQrZAG65, and ssrQrZAG112) might be useful for other purposes such as mapping.

\section{Literature Cited}

Akkak A., D. Marinoni, and R. Botta. 1998. Conservation of polymorphic simple sequence repeat loci in Rosaceae species, p. 93. XV Eucarpia Congress Genetics and Breeding, Viterbo (Italy). 20-25 Sept.

Barreneche T., C. Bodenes, C. Lexer, J.F. Trontin, S. Fluch, R. Streiff, C. Plomion, G. Roussel, H. Steinkellner, K. Burg, J.M. Favre, J. Glöss, and A. Kremer. 1998. A genetic linkage map of Ouercus robur L. (pedunculate oak) based on RAPD, SCAR, microsatellite, minisatellite, isozyme and $5 \mathrm{~S}$ rDNA markers. Theor. Appl. Genet. 97:1090-1103.

Barreneche T., M. Casasoli, K. Russel, A. Akkak, Meddour H., Plomion C., F. Villani, and A. Kremer. 2003. Comparative mapping between Quercus and Castanea using simple-sequence repeats (SSRs). Theor. Appl. Genet. (published online 16 Oct. 2003).

Botta R., A. Akkak, D. Marinoni, G. Bounous, S. Kampfer, H. Steinkellner, and C. Lexer 1999. Evaluation of microsatellite markers for characterizing chestnut cultivars. Acta Hort. 494:277-282.

Botta R., D. Marinoni, G. Beccaro, A. Akkak, and G. Bounous. 2001. Development of a DNA typing technique for the genetic certification of chestnut cultivars. For. Snow Landsc. Res. 76(3):425-428.

Brookfield, J.F.Y. 1996. A simple new method for estimating null allele frequency from heterozygote deficiency. Mol. Ecol. 5:453-455.

Buck E.J., M. Hadonou, C.J. James, D. Blakesley, and K. Russel. 2003. Isolation and characterization of polymorphic microsatellites in European chestnut (Castanea sativa Mill.). Mol. Ecol. Notes 3:239-241.

Callen D.F., A.D. Thompson, Y. Shen, H.A. Philips, R.I. Richards, J.C. Mulley, and G.R. Sutherland. 1993. Incidence and origin of "null" alleles in the (AC)n microsatellite markers. Amer. J. Human Genet. 52:922-927.

Casasoli M., C. Mattioni, M. Cherubini, and F. Villani. 2001. A genetic linkage map of European chestnut (Castanea sativa Mill.) based on RAPD, ISSR and isozyme markers. Theor. Appl. Genet. 102:1190-1199.

Cipriani G., G. Lot, W.G. Huang, M.T. Marrazzo, E. Peterlunger, and R. Testolin. 1999. AC/GT and AG/CT microsatellite repeats in peach [Prunus persica (L.) Batsch]: Isolation, characterisation and cross-species amplification in Prunus. Theor. Appl. Genet. 99:65-72.

Di Gaspero G., E. Peterlunger, R. Testolin, K.J. Edwards, and G. Cipriani. 2000. Conservation of microsatellite loci within the genus Vitis. Theor. Appl. Genet. 101:301-308.

Downey S.L. and A.F. Iezzoni. 2000. Polymorphic DNA markers in black cherry (Prunus serotina) are identified using sequences from sweet cherry, peach and sour cherry. J. Amer. Soc. Hort. Sci. 125:76-80.

Fineschi S., D. Taurchini, G. Müller-Starck, and M. Conedera. 1993. Genetic characterization of cultivated varieties of European chestnut (Castanea sativa Mill.) in Southern Switzerland, p. 309-313. III. Analysis of RAPD molecular markers. Intl. Congr. Chestnut, Spoleto, Italy. 20-23 Oct. 
Goulao L. and C.M. Oliveira 2001. Molecular characterization of cultivars of apple (Malus $\times$ domestica Borkh.) using microsatellite (SSR and ISSR) markers. Euphytica 122:81-89.

Goulao L., T. Valdiviesso, C. Santana, and C.M. Oliveira. 2001. Comparison between genetic characterisation using RAPD and ISSR markers and phenotypic data of cultivated chestnut (Castanea sativa Mill.). Genet. Resour. Crop Evol. 48:329-338.

Hodgetts R.B., M.A. Aleksiuk, A. Brown, C. Clarke, E. Macdonald, S. Nadeem, and D. Khasa. 2001. Development of microsatellite markers for white spruce (Picea glauca) and related species. Theor. Appl. Genet. 102:1252-1258.

Hornero J., F.J. Gallego, I. Martìnez, and M. Toribio. 2001. Testing the conservation of Quercus spp. microsatellites in the cork oak $Q$. suber L. Silvae Genet. 50:162-167.

Huang W.G., G. Cipriani, M. Morgante, and R. Testolin. 1998. Microsatellite DNA in Actinidia chinensis: Isolation, characterisation and homology in related species. Theor. Appl. Genet. 97:1269-1278.

Kampfer S., C. Lexer, J. Glossl, and H. Steinkellner. 1998. Characterization of (GA)n microsatellite loci from Quercus robur. Hereditas 129:183-186.

Kijas J.M.H., J.C.H. Fowler, and M.R. Thomas. 1995 An evolution of sequence tagged microsatellite site markers for genetic analysis within Citrus and related species. Genome 38:349-355.

Kubisiak T.L., F.V. Hebard, C.D. Nelson, Jiansu Zhang, R. Bernatzky, H. Huang, S.L. Anagnostakis, and R.L. Doudrick. 1997. Molecular mapping of resistance to blight in an interspecific cross in the genus Castanea. Phytopathology 87:751-759.

Marinoni D. 2000. Caratterizzazione ed impiego di marcatori microsatelliti per lo studio del germoplasma piemontese di castagno (Castanea sativa Mill.). PhD diss. Univ. Torino, Italy.

Marinoni D., A. Akkak, G. Bounous, K.J. Edwards, and R. Botta. 2003. Development and characterization of microsatellite markers in Castanea sativa (Mill.). Mol. Breed. 11:127-136.

Nei M. 1973. Analysis of gene diversity in subdi- vided populations. Proc. Nat. Acad. Sci. USA 70(12)part I:3321-3323.

Paffetti D., E. Bellini, C. Benelli, and R. Giannini. 1999. Production of probes for the chestnut genotypes by RAPD markers. Acta Hort. 494:287-294

Paetkau D., W. Calvert, I. Stirling, and C. Strobeck. 1995. Microsatellite analysis of population structure in canadian polar bears. Mol. Eco. 4:347-354.

Pereira-Lorenzo S. and J. Fernandez-Lopez. 1993. Intra and intercultivar variability by isozymes characters for some important chestnut cultivars in Galicia, Spain, p. 291-294. Intl. Congr. Chestnut, Spoleto, Italy. 20-23 Oct.

Pereira-Lorenzo S., J. Fernandez-Lopez, and J. Moreno-Gonzales. 1996. Variability and grouping of northwestern Spanish chestnut cultivars (Castanea sativa). II. Isoenzyme traits. J. Amer. Soc. Hort. Sci. 121:190-197.

Pereira M.J.P., L.F.T. Castro, J.M.G. Torres- Pereira, and S.P.Lorenzo. 1999. Isozyme polymorphisms in Portuguese chestnut cultivars. Acta Hort. 494:283-286.

Rajora O.P., M.H. Rahman, S. Dayanandan, and A. Mosseler. 2001. Isolation, characterization, inheritance and linkage of microsatellite DNA markers in white spruce (Picea glauca) and their usefulness in other spruce species. Mol. Gen. Genet. 264:871-882.

Rossetto M., J. McNally, and R.J. Henry. 2002. Evaluating the potential of SSR flanking regions for examining taxonomic relationships in the Vitaceae. Theor. Appl. Genet. 104:61-66.

Santana C., C.M. Oliveira, and T. Valdiviesso. 1999. Molecular typing of rootstock hybrids (Castanea sativa $\times$ Castanea crenata) and Portuguese Castanea sativa cultivars based on RAPD markers. Acta Hort. 494:295-302.

Sefc K.M., F. Regner, E. Turetschek, J. Glössl, and H. Steinkellner. 1999. Identification of microsatellite sequences in Vitis riparia and their applicability for genotyping of different Vitis species. Genome 42:1-7.

Steinkellner H., C. Lexer, E. Turetschek, and J. Glössl. 1997a. Conservation of (GA)n microsatellite loci between Quercus species. Mol.
Ecol. 6:1189-1194.

Steinkellner H., S. Fluch, E. Turetschek, C. Lexer, R. Streiff, A. Kremer, K. Burg, and J. Glossl. 1997b. Identification and characterization of (GA/GT)n microsatellite loci from Quercus petraea. Plant Mol. Biol. 33:1093-1096.

Tanaka K., Y. Tsumura, and T. Nakamura. 1999. Development and polymorphism of microsatellite markers for Fagus crenata and the closely related species, F. japonica. Theor. Appl. Genet. 99:11-15.

This P., A. Jung, P. Boccacci, J. Borrego, R. Botta, L. Costantini, M. Crespan, G.S. Dangl, C. Eisenheld, F. Ferreira-Monteiro, S. Grando, J. Ibáñez, T. Lacombe, V. Laucou, R. Magalhaes, C.P. Meredith, N. Milani, E. Peterlunger, F. Regner, L. Zulini, and E. Maul. 2004. Development of a standard set of microsatellite reference alleles for identification of grape cultivars. Theor. Appl. Genet. (in press).

Thomas M.R., S. Matsumoto, P. Cain, and N.S. Scott. 1993. Repetitive DNA of grapevine: Classes present and sequences suitable for cultivar identification. Theor. Appl. Genet. 86:173-180

Villani F., M. Pigliucci, S. Benedettelli, and M. Cherubini. 1991. Genetic differentiation among Turkish chestnut (Castanea sativa Mill.) populations. Heredity 66:131-136.

Villani F., M. Pigliucci, M. Cherubini, O. Sun and L. Parducci. 1993. Genetic diversity of Castanea sativa Mill. in Europe: Theoretical aspects and applied perspectives, p. 281-284. International Congress on Chestnut, Spoleto, Italy. 20-23 Oct.

Wagner H.W. and K.M. Sefc. 1999. IDENTITY 1.0. Centre for Applied genetics, Univ. Agr. Sci., Vienna.

Yamamoto T., T. Shimada, K. Kotobuki, Y. Morimoto, and M. Yoshida. 1998. Genetic characterization of Asian chestnut varieties assessed by AFLP. Breed. Sci. 48:359-363.

Yamamoto T., T. Kimura, Y. Sawamura, K. Kotobuki, Y. Ban, T. Hayashi, and N. Matsuta 2001. SSRs isolated from apple can identify polymorphism and genetic diversity in pear. Theor. Appl. Genet. 102:865-870. 